\title{
A Case of Unilateral Absence of the Submandibular Gland Secondary to Sialolithiasis
}

\author{
Dongbin Ahn, Bum Soo Chun, Jin Ho Sohn and Junesik Park \\ Department of Otorhinolaryngology-Head and Neck Surgery, School of Medicine, Kyungpook National University, Daegu, Korea
}

\author{
타석증에 의해 이차적으로 발생한 일측 악하선 결손 1예 \\ 안동빈 · 전범수 · 손진호 · 박준식 \\ 경북대학교 의과대학 이비인후-두경부외과학교실
}

\author{
Received August 30, 2010 \\ Revised September 8, 2010 \\ Accepted September 28, 2010 \\ Address for correspondence \\ Junesik Park, MD \\ Department of Otorhinolaryngology- \\ Head and Neck Surgery, \\ School of Medicine, \\ Kyungpook National University, \\ 50 Samdeok-dong 2-ga, Jung-gu, \\ Daegu 700-721, Korea \\ Tel $+82-53-420-5783$ \\ Fax $+82-53-423-4524$ \\ E-mail junesik@knu.ac.kr
}

\begin{abstract}
Absence of major salivary glands, especially those of occurring unilaterally or secondary to Wharton's duct stone, is a rare disorder, A case of unilateral submandibular gland absence occurring secondary to Wharton's duct stone was presented in a 51-year-old male. Using the ultrasonography (USG) and computerized tomography (CT), the absence of the submandibular gland was confirmed. The patient had long-term history of sialolithiasis of the right submandibular gland, so the right submandibular gland was suspected of having acquired a change due to sialolithiasis. The present case would be a second report demonstrating a case of unilateral submandibular gland absence occurring secondary to stones, suggesting that, without ligation of submandibular nerves, the obstruction of excretory duct of a submandibular gland could lead to a complete atrophy of the gland in human.
\end{abstract}

Korean J Otorhinolaryngol-Head Neck Surg 2011;54:154-7

Key Words Submandibular gland $\cdot$ Atrophy $\cdot$ Sialolithiasis.

\section{서 론}

타액선 결손증은 이비인후과 영역에서 드물게 발견되는 질환의 하나로 주로 이하선, 악하선 등의 주타액선에서 발 생하며, 그 병태생리에 따라 선천성 혹은 원발성 타액선 무 형성증과 후천성 혹은 이차성 타액선 결손증으로 구분할 수 있다. 선천성 타액선 무형성증의 경우 이차성 타액선 결손의 원인이 될 수 있는 외상, 결석 등으로 인한 타액선관의 폐쇄 소견과 관련 증상 없이, 발생학적으로 제 1,2 새궁과 관련 된 다른 안면 기형이 동반되면서 타액선 결손이 양측성 혹 은 다발성인 경우 의심할 수 있는데, 이는 현재까지 보고된 타액선 결손 증례의 대부분을 차지하고 있다. ${ }^{1-3)}$ 선천적인 경 우와 달리, 주타액선관을 결찰하여 주타액선관의 폐쇄가 만 들어진 상황에서 해당 타액선의 이차적인 위축이 발생한다 는 것은 Osailan 등 ${ }^{4}$ 의 동물 연구를 통해 확인되었으며, 그 기전에 대해서는 주로 타액선관 폐쇄로 인한 반복적인 타액
선염의 발생과 더불어 타액선관의 폐쇄 자체가 타액선의 타 액 분비 기능에 부정적 되먹임 기전으로 작용한다는 것들로 설명되어진다. 하지만 실질적으로 임상에서 타석증으로 인해 이차적으로 타액선의 완전 결손이 발생하는 경우는 매우 드 문데, 이는 대부분의 환자들이 반복적인 타석증의 증상으로 인해 타액선의 결손이 발생하기 전에 타석 제거술을 받을 뿐 만 아니라, 악하선에 강한 trophic signal을 전달하는 악하 선의 부교감 신경의 차단이 동반되지 않은 주악하선관의 폐 쇄만으로는 악하선이 심한 위축에 이르는 데 한계가 있기 때 문인 것으로 생각된다. ${ }^{4)}$ 이처럼 현재까지 타석증에 의해 이 차적으로 발생한 악하선 결손이라고 추정되는 증례는 $\mathrm{Ga}-$ rcía-Consuegra 등ㅎㅇㅔ 의해 보고된 2예만이 알려져 있다. 이에 저자들은 악하선관 결석을 동반한 반복적인 타액선염 의 병력을 가진 환자에서 반대측 악하선의 보상성 비후를 동반한 일측 악하선 결손을 경험하였기에 이를 문헌 고찰과 함께 보고하는 바이다. 


\section{증 례}

51세 남자 환자가 일주일간의 좌측 악하선 부위의 종창 및 동통을 주소로 내원하였다. 환자는 내원 3 4년 전부터 식사 후에 간헐적으로 반복되는 우측 악하선 부위의 종창 및 동통과 만성적인 구강 건조감을 호소하고 있었으며, 증상 이 심할 때마다 개인의원 또는 약국에서 임의로 약물을 복 용한 병력이 있었다. 수년간 반복되던 우측 악하선의 증상은 내원 3 4개월 전부터 현저히 감소되었으며, 이후 큰 불편 없이 지내다 내원 1 주 전부터 과거 우측에서의 경우와 유사 한 증상이 좌측에 발생하여 개인의원에서 타액선염 의심하에 본원으로 전원되었다. 내원 당시 환자는 육안으로도 좌측 악 하선 부위가 우측에 비해 저명하게 비대되어 있는 것을 알 수 있었으며, 구강검사 및 양수 촉진검사상 우측 악하선관 원위부에서 결석으로 의심되는 매우 단단한 종물이 촉지되

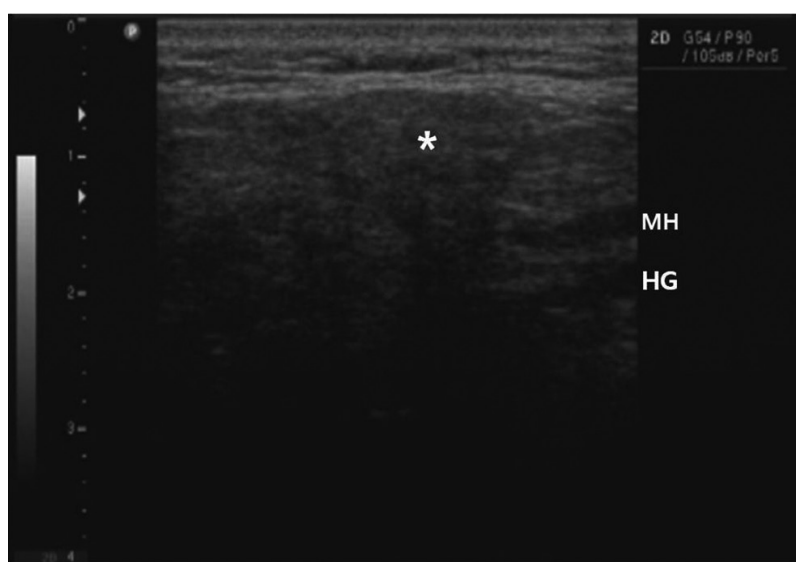

Fig. 1. Ultrasonography shows fat-like tissue with heterogenous and hypoechoic texture at the location of sumandibular gland. $\mathrm{MH}$ : mylohyoid muscle, HG: hyoglossus muscle.
었으나, 종창된 좌측 악하선 부위에서는 특별한 이상 소견 을 발견할 수 없었다. 악하선관의 폐쇄 여부를 확인하기 위 하여 좌측 악하선을 압박해 보았을 때, 환자는 경한 압통을 호소하였으나 구강 내로 타액 분비가 원활히 되는 것을 확인 할 수 있었다. 저자들은 상기 병력 및 신체검사상 우측 악하 선의 타석증 및 좌측 악하선의 타액선염을 의심하여 경부 초 음파검사를 우선 시행하였다. 우측 악하선 부위의 초음파검 사상 일반적으로 악하선이 위치하는 하악설골근 및 설골설 근과 이복근의 후복 사이에서 정상 악하선과는 달리 주위 지방 조직과 유사한 저음영(hypoechoic)의 불균질한 (heterogenous) 소견을 보였으며(Fig. 1), 악하선관의 원위부에 서는 구강검사 시 촉지되었던 결석을 확인할 수 있었으나, 그 근위부의 악하선관의 확장은 동반되지 않았다. 이후 추가적 으로 시행한 전산화단층촬영에서 우측 악하선은 관찰되지 않았고 지방조직으로 해당 부위가 대체되어 있었으며, 타액 선 조직의 흔적으로 생각되는 연부조직 음영이 지방조직 내 부에 일부 흩뿌려져 있는 양상을 보였다(Fig. 2A). 우측 악 하선관 부위에서는 약 $0.8 \mathrm{~cm}$ 크기의 악하선관 결석을 확인 할 수 있었으며 좌측 악하선은 약간 비대되어 있었으나(Fig. $2 \mathrm{~B})$, 동측 및 반대측 설하선의 비대칭 등 다른 특이 소견을 발견할 수 없었다(Fig. 2C).

환자의 우측 타석증으로 인한 증상은 약 1년 전부터 서서 히 호전되기 시작한 이후 내원 당시에는 그에 대한 불편을 크게 호소하지 않았다. 하지만 폐쇄되었던 악하선관의 재개 방 시 일부 잔존해 있을 악하선 조직의 회복 가능성을 염두 에 두고 국소마취하 타석제거술을 시행하였다. 타석 제거 후에 악하선 압박으로 타액의 분비를 유도해보았으나 구강 내로 타액이 분비되는 것을 확인할 수는 없었으며, 이후 악
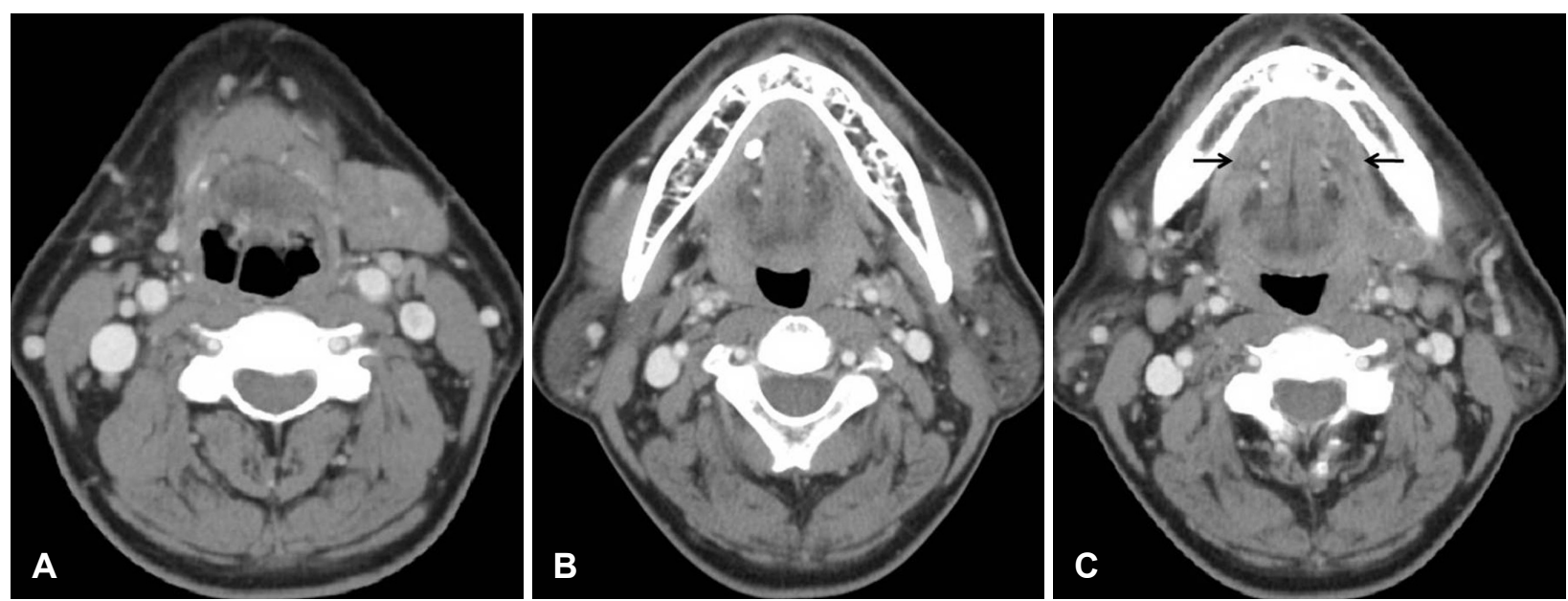

Fig. 2. Axial neck CT scan demonstrate absence of the right submandibular gland and Wharton's duct stone. Right submandibular gland is replaced by fat tissue and scattered soft tissue density is seen which is considered as remnants of atrophied gland (A). The stone has about $0.8 \mathrm{~cm}$ in diameter and is located at the distal portion of duct (B). Both sublingual gland (arrows) are symmetrical and evident hypertrophy of gland is not seen (C). 


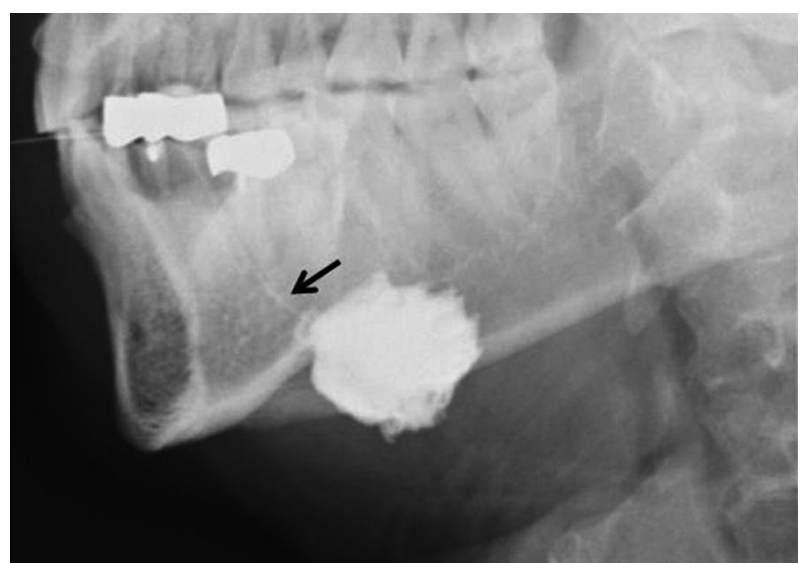

Fig. 3. Sialography reveal faint Wharton's duct and stasis of contrast at floor of mouth, suggesting severe atrophy of proximal Wharton's duct and submandibular gland parenchyma.

하선관 결석이 존재하던 위치로 도관을 삽입하여 타액선 조 영술을 시행하였을 때 조영제가 악하선으로 정상적으로 유 입되지 못하고 구강저에 저류되는 소견만을 관찰할 수 있었 는데, 이는 결손된 악하선과 함께 악하선관 근위부의 심한 위축으로 인해 나타나는 소견으로 생각되었다(Fig. 3). 좌측 악하선의 타액선염에 대한 치료로는 항생제 및 진통 소염제 등의 약물치료 및 국소온열요법, 악하선 마사지 등을 시행하 였으며, 약 1 주일간의 치료로 상기 증상은 소실되었으나, 육 안적인 좌측 악하선의 비대는 남아있는 상태로 현재 약 6 개 월간의 경과 관찰 기간 동안 정기적인 신체검사 및 초음파검 사상 우측 악하선 조직의 회복 징후는 아직 없는 상태이다.

\section{고 찰}

타액선의 선천적 결손은 매우 드물게 발생하는 두경부 기 형으로 전세계적으로 약 30예에서만 보고되었으며, 주로 양측성, 다발성으로 발생하는데 현재까지 단지 6 예의 일측 성 악하선 무형성증만이 보고되고 있다. ${ }^{6-8)}$ 이러한 주타액선 의 선천성 무형성증은 하악안면골이골증(Treacher-Collins syndrome), 반안면왜소증(hemifacial microsomia), 눈물관-귓바퀴-이-손발가락 증후군(lacrimo-auriculodento-digital syndrome) 등의 다른 안면기형을 동반하는 것을 근거로, 태아 제 1 및 제 2 새궁 외배엽의 정상적인 발 달장애로 인한 것이라는 주장이 제시되고 있지만 정확한 원 인 및 병태생리는 아직 밝혀져 있지 않다.,2,5) 선천적 무형성 증과는 달리, 후천적인 타액선의 결손은 발생학적으로 연관 된 다른 부위의 기형을 동반하지 않으며 타액선관의 결찰이 나 타석증으로 인해 발생한 만성적인 타액선염에 이은 위축 성 변화의 결과로 발생할 수 있으나, ${ }^{4,5)}$ 이에 대한 보고는 매 우 드물어 저자들이 대한이비인후과학회지, 한국의학논문
데이터베이스, pubmed 등을 통한 검색 결과 타석증으로 인 해 이차적으로 발생한 악하선의 결손을 보고한 경우는 국내 외적으로 García-Consuegra 등히이 보고한 2예만 확인할 수 있었다. 하지만 García-Consuegra 등이 보고한 2예 중 두 번째 증례의 경우 이전의 타석증으로 인한 증상은 전혀 없 이 치과 검진을 위해 시행한 단순 방사선검사상 결석이 우연 히 발견된 경우로, 타석증에 의한 반복적인 타액선염의 이차 적인 결과로 악하선 결손이 발생했다고 주장하기에는 무리가 있을 것으로 사료된다. García-Consuegra 등희의 발표에 앞 서 이와 비슷하게 Koo 등히이 악하선 무형성증과 동반된 악 하선관의 결석을 처음으로 보고하였는데, 환자가 이전의 타 석증으로 인한 증상이 전혀 없었던 점을 고려했을 때 기존의 선천성 악하선 무형성증을 갖고 있는 환자에서 맹관을 이루 고 있던 악하선관에 결석이 발생한 것으로 생각하는 것이 타 당하다고 기술한 바 있다. 하지만 본 증례에서는 이와 달리 $3 \sim 4$ 년 전부터 간헐적으로 발생하던 타석증의 증상이 약 $3 \sim 4$ 개월 전부터는 현저히 호전된 병력이 있음을 고려하여 볼 때, 이는 반복적인 타액선염으로 인한 악하선 위축의 과 정을 거쳐 결과적으로 악하선 소실에 이르렀음을 시사하는 임상적 근거가 될 것으로 사료된다. 이와 같은 만성 폐쇄성 타액선염에서 타액선 위축이 발생하는 과정을 병리적으로 살펴보면 초기에는 관세포(ductal cell) 주위의 림프구 침윤 과 관(duct)의 불규칙한 확장이 나타나다가 타액의 울혈이 지속됨에 따라 선방세포(acinar cell)의 위축이 시작되고, 이어서 관세포 주위와 소엽내의 섬유화가 발생하게 되며 지 속적인 섬유화의 진행은 엽구조(lobular architecture)의 파 괴를 야기하여 궁극적으로 기능적 상실을 동반한 타액선 실 질의 소실과 경화에 이르게 된다. ${ }^{7)}$

많은 수의 선천성 타액선 무형성증 증례 보고에서 반대측 타액선의 보상적 비대를 확인할 수 있다고 하였다. ${ }^{8-10)}$ 일측 성 악하선 무형성증의 경우 주로 반대측 악하선의 보상적 비 대가 흔히 관찰되는 소견이나, Srinivasan 등은 전산화단 층촬영과 자기공명영상 등을 이용하여 동측의 설하선의 비 대를 확인하기도 하였다. 본 증례에서도 결손 부위 반대측인 좌측의 악하선은 내원 당시 육안적 비대 소견뿐만 아니라 동 통을 동반하고 있었는데, 이는 우측 악하선의 결손으로 인 한 좌측 악하선의 보상성 비대와 더불어, 활발해진 좌측 악 하선의 분비 기능에 비해 악하선내 악하선관 지류들의 보상 성 증식은 완전히 이루어지지 않아 발생한 악하선 종창이 복합적인 요인으로 작용한 것으로 생각된다. 이러한 경우 치 료로는 악하선내 악하선관 지류들의 보상성 증식이 충분히 이루어질 때까지 타액의 배출을 원활히 해주고, 2 차 감염을 예방하는 것을 목적으로 마사지 요법 및 항생제 사용 등의 
보존적 치료를 시행하여 증상을 조절해 주는 것이 합리적일 것으로 사료된다.

선천성 악하선 무형성증의 임상양상은 증상이 전혀 없는 경우부터 구강 건조증, 저작 및 연하곤란, 충치 등 다양하게 나타날 수 있지만 이들은 모두 비특이적인 증상들로 대부분 의 경우 영상학적 검사상 우연히 발견되는 경우가 흔하였 다. ${ }^{6)}$ 이에 비해 악하선관 결석으로 인해 이차적으로 발생한 악하선 결손의 경우 본 증례에서와 같이 과거 반복적인 타 석증의 증상 및 구강 건조증이 있고, 결석의 수술적 제거가 이루어지지 않았음에도 불구하고 악하선이 위축됨에 따라 서서히 증상이 호전되는 병력을 가지고 있을 때 우선 의심할 수 있겠으나, 확진을 위해서는 초음파나 전산화단층촬영 등 의 영상학적인 검사 반드시 필요하다. ${ }^{11)}$ 특히 전산화단층촬 영에서 정상 타액선이 지방조직으로 대체되는 소견은 쉽게 확인할 수 있지만, 이러한 경우 타액선에서 발생할 수 있는 단순 지방종 및 2001년 Nagao 등 ${ }^{12}$ 에 의해 처음으로 보고 된 sialolipoma 등의 지방조직이 풍부한 다른 종양들을 반 드시 감별해야 한다.

본 증례는 타석증에 의해 이차적으로 발생한 악하선 결손 의 두 번째 보고로 생각된다. 특히 이전 보고에 비해 이차성 악하선 결손에 부합하는 비교적 특징적인 임상을 가지고 있 다는 점에서 주목할만 하였고, 전산화단층촬영, 타액선 조영 술을 통해 의심되었던 악하선의 완전 결손을 수개월간의 추 적관찰로 확인할 수 있었다. 또한 악하신경의 차단 없이 단 지 악하선관의 폐쇄에 의해서도 악하선의 완전 위축이 발생 할 수 있다는 것을 보여주는 증례로, 저자들은 문헌고찰과 함께 이를 보고하는 바이다.

\section{REFERENCES}

1) Matsuda C, Matsui Y, Ohno K, Michi K. Salivary gland aplasia with cleft lip and palate: a case report and review of the literature. Oral Surg Oral Med Oral Pathol Oral Radiol Endod 1999;87(5):594-9.

2) Singh P, Warnakulasuriya S. Aplasia of submandibular salivary glands associated with ectodermal dysplasia. J Oral Pathol Med 2004;33(10):634-6.

3) Kubo S, Abe K, Ureshino T, Oka M. Aplasia of the submandibular gland. A case report. J Craniomaxillofac Surg 1990;18(3):119-21.

4) Osailan SM, Proctor GB, McGurk M, Paterson KL. Intraoral duct ligation without inclusion of the parasympathetic nerve supply induces rat submandibular gland atrophy. Int J Exp Pathol 2006;87(1):41-8.

5) García-Consuegra L, Rosado P, Gallego L, Junquera L. Unilateral absence of submandibular gland secondary to stones. Aplasia versus early atrophy. Med Oral Patol Oral Cir Bucal 2010;15(5):e752-4.

6) Koo BS, Lee SW, Lee YM, Lee JD, Koh YW. Sialolithiasis in a stump of Wharton's duct of an aplastic unilateral submandibular gland. Int J Oral Maxillofac Surg 2009;38(1):93-5.

7) Teymoortash A, Tiemann M, Schrader C, Werner JA. Characterization of lymphoid infiltrates in chronic obstructive sialadenitis associated with sialolithiasis. J Oral Pathol Med 2004;33(5):300-4 .

8) Srinivasan A, Moyer JS, Mukherji SK. Unilateral submandibular gland aplasia associated with ipsilateral sublingual gland hypertrophy. AJNR Am J Neuroradiol 2006;27(10):2214-6.

9) Whyte AM, Hayward MW. Agenesis of the salivary glands: a report of two cases. Br J Radiol 1989;62(743):1023-6.

10) Yilmaz MD, Yücel A, Dereköy S, AltuntaşA. Unilateral aplasia of the submandibular gland. Eur Arch Otorhinolaryngol 2002;259 (10):554-6.

11) Jeong HS, Koo GJ, Kim YC, Koo SK. Unilateral parotid glandular aplasia and ductal atresia. Korean J Otolaryngol-Head Neck Surg 1999;42(3):377-9.

12) Nagao T, Sugano I, Ishida $Y$, Asoh A, Munakata $S$, Yamazaki $K$, et al. Sialolipoma: a report of seven cases of a new variant of salivary gland lipoma. Histopathology 2001;38(1):30-6. 